\title{
En Oplysning.
}

Da Hr. Dr. phil. Holger Pedersen i sin interessante Afhandling om "Sprogvidenskaben" navner og angriber en Hr. K. B. i „Dannebrog ", beder jeg den ærede Redaktion oplyse, at jeg ikke er Forfatteren til nævnte Artikler eller har gjort mig skyldig i Misforstaaelser af nærnte Art, som jo ikke kunde undskyldes for en Lærer i nordiske Sprog, ligesom jeg, siden „Dannebrog"s Medarbejder har anvendt det samme Mærke som jeg, overbovedet aldrig i noget Tidsskrift eller Blad optræeder under andet Mrrke end mit fulde Nan.

Kobenhavn, 10. Oktbr. 1899.

Frbødigst

Knud Bokkenheuser. 


\section{„Sonderjydske Aarbgeger"}

udgivne af

H. P. Hanssen-Norpemolle, Gustar Jobannisen of P. Shau

udkommer to Gange aarlig i Hæfter paa 10 Ark.

"Sonderjydske Aarboger"6 bringe Bidrag til Slesvigs Historie og Topographi, Skilhringer af Folkelivet i Nordslesvig, historiske og andre videnskabelige Afhandlinger m. m.

Subskription paa "Sinderjydske Aarbyger" modtages i alle Ioglader i Slesvig, Danmark, Norge og Sverrig. Prisen er 4 Lroner Aargangen; for Merilemmer af danske Foreninger i Nordklesvits :3 Mark.

\section{Indhold:}

1'. Lamiduen VI:lem Slagenc. En Fremstilling on den civile Kamp um Sumierjwiland 1849- .0 . . . Side 181.

Julutu Ottuen: A. I). Tnrgensen. Nugle mindeurd. . . 2is.

\section{$\vdots=\vdots \quad \vdots$}

